\title{
Obituary
}

\section{Professor Jean Holowach Thurston: Renowned and True Pioneer of Pediatric Neurology as Well as Neurochemist}

Jean Holowach Thurston, MD, (June 22, 1917April 29, 2017) was at forefront of research into seizure disorders, Professor Emeritus at Washington University School of Medicine in St Louis, academician, mentor, and great teacher, who embodied pediatric neurology decades before the emergence of pediatric neurology as true discipline, lifelong learner, a great speaker, interlocutor, and spontaneous mentor. She was the first to demonstrate important differences between energy metabolism in the developing brains compared to the adult brains in her pioneering studies and fondly well known for her cerebral metabolic studies in the infant and children across the globe.

Jean Holowach Thurston was born and also completed early education at Edmonton, Canada. Thurston completed medical graduation at the University of Alberta in Edmonton in 1941. She started 2-year fellowship in pediatrics with interest in metabolism in 1945, at Washington University School of Medicine. Further, Thurston also completed special U.S.P.H.S. NINDB neurochemistry fellowship at the prestigious laboratory of Oliver Lowry over 1962-1965.

During the second phase of academic career, Prof. Holowach Thurston got appointment as instructor in the Department of Pediatrics at St. Louis in the year 1949 and promoted to Assistant Professor in 1954, and subsequently, also to Associate Professor in 1965. In 1950, she founded the pediatric Convulsion Clinic and served as its director until 1962 and additionally, served as director for the State of Missouri Premature Program over 1949-1961. She was appointed as Professor of Pediatrics in 1975 and also got charge as Professor of Neurochemistry division of Neurology in 1982. She was named as Professor Emeritus in 1987.

In the third phase of academic and Professional life, Prof. Holowach Thurston continued research, established own neurochemistry laboratory, and continued scientific writing, research, and publications till the 78 years of her age and further also continued to regularly attending Professional seminars until only a year before her demise.

Prof. Holowach Thurston was said to a true pioneer of pediatric neurology and embodied pediatric neurology decades before the discipline emerged. She was very fondly concerned with clinical aspects of epilepsy, including studies of the efficacy of acetazolamide and ACTH. She led long-term studies examining anticonvulsant withdrawal effects in the pediatric patients with epilepsy and identified various risks factors responsible for the recurrence of seizure by clearly demonstrated specific seizure type strongly influenced the risk of recurrence, and along with identification of other factors.

To pursue pediatric cerebral metabolic studies, Prof. Holowach Thurston investigated and promptly applied the task of validating and improving the sensitive assays designed to estimate the activity of mitochondrial enzymes and intermediates in a relatively very small volume of tissue samples.

Prof. Holowach Thurston investigated the effect of developing brain to the exhaustion of energy reserves along with toxic and adverse effect produced by the accumulation of toxic metabolic products on prolonged administration of glucose, insulin, glycerol, hydrocortisone, and aminophylline, to improving the outcome of babies. She also studied the effects of malnutrition on cerebral energy metabolism, for example, brain uptake and utilization of energy sources such as fructose. Prof. Holowach Thurston demonstrated important differences between energy metabolism in the developing and mature brain concerning the effects of anoxia, hypoxia, and ischemia on the availability of energy substrates, and advocated serum glucose was an unreliable index of brain glucose and glucose supplementation improved outcome in the infants and small children in the anoxic events, which is contrary to common observed phenomenon in adult population.

Her knowledge of brain metabolism and neurochemistry was legendary as she had active interest in pediatric hypoglycemia, gastrointestinal diseases, and pediatric cancer. In another pioneering study, she documented the association between breath holding and anemia.

Prof. Holowach Thurston received several awards including the Foment-Peterson Founders Award from the Midwest Society for Pediatric Research in 1990 in recognition for fostering advances in pediatric research, and the first lifetime achievement award by the Child Neurology Society, in 2004, for her contributions to the field of child neurology.

She always continued learning and mastered e-mail writing at the age of 88 years, and completed human-studies training at the age of 93-years only to start a new scientific research study in pediatric population. Prof. Holowach Thurston inspired generations of physician-scientists. Prof. Thurston was also a dedicated 
opera buff, an avid gardener, and a fantastic cook. She always remained tireless learner, establishing her own neurochemistry laboratory, where she continued to make seminal contributions. She used to enjoy life to the fullest extent each and every day with special love for adventure, travel, nature, and golf.

She and her husband, late Prof. Donald L. Thurston, and retired Professor of Pediatrics, also served at Washington University, the dedicated couple collaborated on various research projects, were also known for advocating and mentoring the younger colleagues. She always made extraordinary efforts to facilitate junior researchers. She had lot of happy patients treated by her, pediatrician and neurologist, who were mentored by her practicing across the globe.

Guru Dutta Satyarthee

Department of Neurosurgery, All India Institute of Medical Sciences, New Delhi, India
Address for correspondence: Dr. Guru Dutta Satyarthee, Department of Neurosurgery, Neurosciences Centre, All India Institute of Medical Sciences, Room No. 714, New Delhi, India. E-mail: duttaguru2002@yahoo.com

This is an open access article distributed under the terms of the Creative Commons Attribution-NonCommercial-ShareAlike 3.0 License, which allows others to remix, tweak, and build upon the work non-commercially, as long as the author is credited and the new creations are licensed under the identical terms.

\begin{tabular}{|l|l|}
\hline \multicolumn{2}{|c|}{ Access this article online } \\
\hline Quick Response Code: & Website: \\
\hline
\end{tabular}

